\title{
Trainer Motives in Training Communication
}

\author{
Rismawaty \\ Communication Studies Program \\ Universitas Komputer Indonesia \\ Bandung, Indonesia \\ Rismawaty@email.unikom.ac.id
}

\begin{abstract}
This study aims to construct about the trainers and communication motive instead of the trainer in providing training toward the communication context. The method used in this study is phenomenology under the paradigm constructivist and interpretive analysis techniques. The data collection techniques used are indepth interviews and participant observation. Data validation is done through: extended observation, increased persistence, triangulation, and discussion with colleagues. The study findings should be concluded that the trainer's motives will be grouped into two, namely trainers' motives and trainers' communication. To be happy as a motive trainer in public speaking, should be active in organization, having a sense of sharing, and being inspired by a book. While the communicating motives trainers are there: 1 . in order to motive among others: hope trainers (can be useful for themselves, myself and others and provide inspiration and goals for trainers (trainers as motivators and inspirers). 2. Correlation of motive among others: the attitude of trainers (learning partners, friendly, and good prejudice) and attract attention (giving surprises, friendly with problems, smiles, ice breaking, brain breaking, eye breaking, games). Suggestions from this research are being able to conduct further research that focuses on trainer's communication experience in one special training.
\end{abstract}

Keywords: Trainer, Communication, Training Communication, Motive.

\section{I.INTRODUCTION}

This study deals with the trainer motives in training communication beyond the study of deep trainer phenomenology training communication in Bandung. Communication training is an activity process communication by trainers in providing training. It can't be denied that the aspects of communication in training play an important role from implementation starting until the end of training activity that was carried out. Sure, in training, the skills are needed in communication by the trainer in the first time to know the trainer's ability delivering materials, the ability to build a conducive relationship with trainees in

Training communication. This researcher differ from previous research, because the previous research studies focusing more on perceptions or opinions of overcoming the obstacles that occurred when the training takes places. [1] Defines that training as a series of activities which is designed to improve the kills, knowledge, experience, or change in the attitude of an individual. While in Presidential Instruction No. 15 of 1974, the definition of training is formulated as follows: Training is a part of education regarding the learning process to obtain and improve the skills outside of the prevailing education system, within the time frame which is relatively short, and by using methods that prioritize practice instead of theory [2].

For the time being, it cannot be denied that the company has budgeted every year $20-30 \%$ of the budget is aimed at developing human resources. One of them is through organizing trainings such as those submitted during the interview of researchers with one research informants: "In 2005, when I launched Indonesian Training Magazine, the first media was on Indonesia which presents information about the world of training and resource developers man, I once said: "About 10 years from now, managerial conception will developing. If today you know the Manager-Leader model, then you will later entering the era of Manager - Trainer. Where managers will be directly involved in the effort training human resources, analyze needs, design programs, up to evaluate the training ".

Today, in early 2015, there were many training centers transformed into Corporate University, even some organizations immediately took it leap into Learning Organization. Where in it training and activities developing human resources is the responsibility of human resources developed itself. Today is 2015 ... who is the Manager - Trainer the real model is happening.

Related with the previous explanation, the researcher does an approach through method research with phenomenology using interview with several Bandung trainers as research informants in order to know more about the motive of the trainer in providing.

trainees on the trainer or trainer. But in this study, focused on training communication trainer. Research results that are relevant to the research of the researcher 
are: a dissertation by [3] Robin Smith Mathis, Participating in the Experience An Exploratory Qualitative Experience in training study, Texas A \& M University, 2010, Participants' views on training experience: A qualitative exploratory study, views or perceptions about training and development continues to emerge in practitioners' literature, but the reality is that these views are not reviewed in the resource development literature human.

The above explanation gives an overview of the research background researchers about the motive of the trainer in providing training communication formulated in the research questions are as follows:

How is the motive of being a trainer in training communications? and What is the motive for communicating by trainers in providing training?

\section{II.RESEARCH METHOD}

This study uses a constructivist paradigm, with interpretive analysis techniques. According to [4] Denzim and Lincoln (1994: 109) The constructivist research paradigm has several characteristics which are really reactive, the meaning is constructed specific, local, subjective, producing knowledge based on the Findings that occurs during the interaction process between researchers and informants. Constructivist views refuse positivism, namely understanding that places the importance of observation and objectivity in finding the reality of science [5] (Salim 2006: 71).

In this study the researcher focused her research based on the phenomenology of Schutz. Schutz's phenomenology in this study is to reconstruct 2experience and motives trainer in the communication aspect. In the view of Schutz humans are social beings, so awareness of the world of daily life is social awareness. Individual world is an inter subjective world with diverse meanings, and feelings as part of group. Humans are required to understand each other, and act in reality the same one. In this phenomenological study a trainer must understand psychological training participants so that the goals and motives set at the beginning by the trainer can be in accordance with the desired expectations.

The subject of this study is a trainer in Bandung. The subject or research informant is a person who knows information about the situation and conditions of the research, so he must have a lot of experience about the research setting [6] (Moleong 2007: 90). As for selection of research subjects with various considerations including:
1. In accordance with the research focus is one of trainer in Bandung

2. Select trainers as informants who already have a training certificate or have experience and has flight hours in providing minimal training as a trainer for 5 years.

3. The chosen trainer has experience or has flight hours as a trainer at the local level (especially Bandung), national or even international level.

4. Trainers who are not only known as trainers but most researchers choose a trainer who is also known by the wider community through his work, namely through a book and other works.

TABLE I TABLE RESEARCH INFORMANT (TRAINER)

\begin{tabular}{|l|l|l|l|}
\hline \multirow{2}{*}{ No } & \multicolumn{2}{|c|}{ Research Informant (Trainer) } & \multicolumn{1}{|c|}{ Name } \\
\cline { 2 - 4 } & \multicolumn{1}{|c|}{$\begin{array}{c}\text { Experienc } \\
\text { e being } \\
\text { trainer }\end{array}$} \\
\hline 1 & Bambang Setiawan (BS) & Trainer & 14 years \\
\hline 2 & Ayi Tejaningrum (AT) & Trainer & 16 years \\
\hline 3 & Paulus Winarto (PW & Trainer & 12 years \\
\hline 4 & Indra Muhtadi (IM) & Trainer & 7 years \\
\hline 5 & Sutanto Windura (SW) & Trainer & 12 years \\
\hline 6 & Neni Yulianita (NY) & Trainer & 12 years \\
\hline 7 & Agung Fatwa (AF) & Trainer & 5 years \\
\hline 8 & Enny Sulistiani (ES) & Trainer & 9 years \\
\hline 9 & Masrukhul Amri (MA) & Trainer & 16 years \\
\hline 10 & $\begin{array}{l}\text { Parlindungan Marpaung } \\
\text { (PM) }\end{array}$ & Trainer & 16 years \\
\hline 11 & $\begin{array}{l}\text { Amirullah } \\
\text { (USA) Syarbini }\end{array}$ & Trainer & 5 years \\
\hline
\end{tabular}

Source: 2014-2015 Research Data

The research object used in this study is the trainer motive and motive communicate trainers in providing training. The approach process used in this research includes structural approaches and personal 
approaches. Data source primary data is used through interviews and observations and secondary data selection. The informant was carried out using purposive sampling technique. Research data collection procedures with phenomenological traditions can follow Creswell's suggestion is called "A Data Collection Circle" [7] (Creswell 1998: 109-135) namely:

\section{Locating site/individual}

2. Gaining Access and Making Report cards3

3. Purposefully sampling

4. Collecting data

5. Recording Information

6. Resolving Information

7. Resolving Field Issues

8. Storing data

This research is in a qualitative angle with the phenomenological tradition there are four techniques for collecting data, namely:

\section{Observation (ranging from nonparticipant to participant)}

2. Interview (ranging from semistructured to openended)

3. Documents (ranging from private to public), Audio Visual

4. Materials (including materials such as photographs, compact disks and videotapes)

[8] (Cresswell, 1998: 120).

\section{III.RESEARCH RESULTS}

In this study, the researcher presents the results of research on the motive of trainers, where the researcher discusses that there are two motives of the trainer, namely, first what is behind the background of the informant research to become a trainer and both motives for communicating deep trainers training communication.

\section{Results of Trainer Communication Research}

The results of the interviews with the research informants obtained data that the motives of being a trainer. There are four of them:

\section{Nice to speak in public}

Talking in front of a crowd for some people is difficult but not for some research informants who like to speak in public. From the results of the interview there are four research informants who originally became trainers were like talking in public, including: PM, BS, IM, and NY, here are excerpts from interviews with BS: "..... my habit of speaking in public during college". (Interview with BS, January 23, 2014)

\section{Active in Organization}

The motive for being a trainer starting from being active in the organization was revealed by informants research of the researchers, namely BS and US. The following is an excerpt from the interview with BS: "...... from the organization, so on campus, I have been active in the organization and me quite a lot to talk there. It turned out to be a profession from the organization not from college ". (Source: Interview with BS, January 23, 2014). The above statement is also supported by US informants through quotations the following interview: "Active in organizations both in school and campus, and often follow speech competition (da'wah) or public speaking ". (Source: Interview with US, September 13, 2014).

3. Having a feeling of willing to share the results of the interview with the informant that the motive of being a trainer is not only happy in speaking publicly and actively organizing, but already grown from within, this reflected in the expressions of the AF, ES, US, MA informants. The following AF phrase is quoted researchers from interview results: "..... Starting from seeing someone else in 2003. From a small child I wanted to share, believe yourself - breaking the habbit. (Source: Interview with AF, January 22, 2014)

\section{Works Through Books}

A book as works, which the author can share knowledge and share experiences his life and expected by pencils that can inspire readers of his work books. From the results of interviews, the researcher shows that informants were almost all have writing through a book, especially PM, ES, US, AF, MA, PW and from books describe about how some research informants were asked to become trainers. The following is the result of the interview with US informants saying the motive of being a trainer starts appears namely: "... Because I am productive in writing books within 3 years that I can finish for making 35 books ... well, from my book, it is used as a theme for my training give, so every training I will have a reference to my book ". (Source: Interview with US, 17 October 2013). Unlike the statement from PM: "... know personally who I am and they know from people, also from books." (Source: Interview with PM, 3 October 2013). 


\section{The Research Results of Trainers' Communication Motives}

\section{Wish be Trainer in Communication Training}

A wish is a sign that someone wants to progress and develop in him. Results of this research through interviews obtained trainer's expectations in training for participants, namely have the ability to communicate or skills in other matters and emotional and intellectual intelligence. The results of the research through interviews are obtained as follows:

a. The trainer's expectation in communicating can be useful for others. The following are the results of the interview with MA informants: "The wish is first, I as a trainer got enlightenment, especially if there were participants who asked or after the activity was finished the participants still shared, both participants got enlightenment which hopefully will be useful for their lives personally and socially ". (Source: Interview with MA, March 9, 2015).

b. Wish that trainers can inspire and give birth to new concepts. According to the US, PW, and BS said the trainer's wishes in training communication were able to provide inspiration and give birth to new concepts, it is conveyed by US informants through quotations from the interview results as follows: "... yes, we hope it's two, ma'am, the training is not just a formality. We want the training to give birth to new concepts that end in action. So there is the result is as even action. The second is measurable, so the training is not once butthere is continuity. The ideal training is indeed a well-prepared training the concept, target, participants are mature, so the capacity is clear. Competence clearly sought ". (Source: Interview with US, March 7, 2018)

\section{Purpose of Trainer Communication in Providing Training}

The results of the research through interviews and observation of the communication objectives of the trainer in giving consisted of two training courses:

\section{As a Motivator}

The research results' purpose of the trainer's communication as a motivator expressed by AT, AF and BS informants are as follows: Except from interview with AT informant: "The motivator is the driving force of someone to do something, the driving force come from yourself ". (Source: interview with AT, June 5, 2014).

\section{As an Inspirator}

The results of the interview with the research informant said that between motivators and inspirers differ in their definition and understanding as conveyed by BS, MA, AT, PM and PW informants. According to the AT infomation, the excerpt from the trainer interview results as an inspiration are as follows : "...... But his inspiration is seeing, analyzing, hearing, getting from what happened is he collaborates with his knowledge, be something. (Source: interview with AT, June 5, 2014)

\section{Discussion}

Humanistic psychology states that humans become more meaningful if they are seen as "being human" not only on the basis of "Humanity" (human being) only. A "process that becomes" is part of the essence human self. In line with the view of humanism, researchers will reveal how the nature of the trainer.

1. Peterson (1990) states in his research that there are five variables that are the most have an effect on the success of the training which is a clear goal, relevant content, techniques right, the ability of the trainer, and who trains. The statement suggests that the presence of qualified trainers has an impact on the success of the training. The successful implementation of training is closely related to increasing knowledge and the ability of trainees.

2. The results show that there are various motives expressed by the people trainers as research informants in choosing the profession. Their motives can be seen from the results of interviews about the initial encouragement, expectations and goals of the informants to become trainers.

3. The motives of the trainers as research informants can also be seen from their chosen goals the profession. Interviews with a number of research informants showed that there were two final goals of the trainer are as motivators and as inspirers.

\section{V.CONCLUSION}

The motive for choosing a profession as a trainer is to refer to the past in order to be happy to speak in public, active in the organization, have a sense of wanting to share and pass book work. The communication skill of the trainer is to refer to the inorder-to-motive depicted in hope that is beneficial for oneself and others. Whereas the purpose trainer in training communication is as a motivator and inspirator.

\section{VI.ACKNOWLEDGMENT}

This research was sponsored by the Ministry of Education Scholarship Assistance Research, Technology and Higher Education of the Republic of Indonesia - Directorate General of Education High Level. 


\section{REFERENCES}

[1] Berger, Peter Ludwiq and Thomas Luckman, "The Social Construction of Reality: A Treatise in The Sociology of Knowledge", New York: Anchor Books, 1966.

[2] Kamil and Mustofa "Model Pendidikan dan Pelatihan (Konsep dan Aplikasi), Penerbit Alfabet, Bandung, 2010.

[3] A Disertasi on by Robin Smith Mathis

[4] Denzim, Norman K and Yvonna S. Lincoln.(ed) "Handbook of qualitative Research" New York, Harper\&Row, 1986.
[5] Charon, Joel M. "Symbolic Interactionism, an Introductions, an Interpretation, an Integration", London: Prentice-Hall.Inc, 1979.

[6] Moleong and Lexy J, "Metedologi Penelitian Kualitatif" PT. Remaja Rosdakarya, Bandung, 2007.

[7] Cresswell and John W, "Qualitative inquiry and Research Design: Choosing Among Five Tradition, Thousand Oaks" Ca, Sage Publication Inc, 1998.

[8] Cresswell and John W, "Qualitative inquiry and Research Design: Choosing Among Five Tradition, Thousand Oaks" Ca, Sage Publication Inc, 1998. 